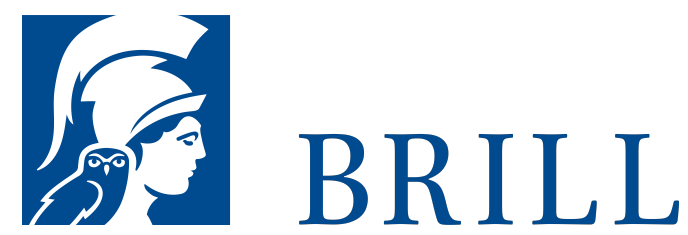

\title{
Die Künste im Gespräch
}

\section{Zum Verhältnis von Kunst, Musik, Literatur und Film}

Authors: Florian Keller, Sabine Gebhardt-Fink, Corina Caduff, Sabine Gebhardt Fink, and Steffen Schmidt

In den Künsten der Gegenwart gehört die Überschreitung herkömmlicher Disziplin- und Mediengrenzen längst zum Alltag. Dieses Buch, verfasst von einem interdisziplinären Autorenteam, reflektiert diese Tendenzen, indem er folgenden Fragen nachgeht: Wie erscheinen bestimmte Themen und Motive - z.B. die Träne, die Ekstase, der Sport - in Kunst, Musik, Literatur und Film, wo zeigen sich ästhetische Differenzen und Analogien, wie kann man umgehen mit geschichtlichen Diskontinuitäten, die sich dabei im Vergleich der Künste ergeben? Thematisch bewegt sich der Band im Spannungsfeld von Hoch- und Alltagskultur.

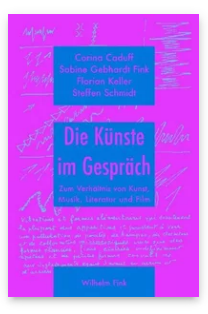

Pages: 156

Seiten, 33 s/w

Abb.

Language:

German

Subjects:

General,

Literature and

Cultural Studies

Publisher: Brill |

Fink

E-Book (PDF)

Released online:

3o Dec 2019

ISBN: 978-3-

8467-4524-3

List price

USD $\$ 28.00$

Paperback

Publication date:

19 Sep 2007

ISBN: 978-3-

7705-4524-7

List price

USD $\$ 28.00$ 
For more information see brill.com

Order information: Order online at brill.com +44330 333 0049 | customerservices@brill.com Submission information: brill.com/authors

Titles published by Brill | Fink, Brill | mentis or Brill | Schöningh: +49(o)715413279216| brill@brocom.de 